\title{
Instrument of self-perception and knowledge of dental erosion: cross-cultural adaptation to the Brazilian population
}

Sandro Bertazzo da SILVA(a) Tanise de Medeiros CABRAL ${ }^{(a)}$ Tatiana Militz Perrone PINTO(b) Letícia Brandão DURAND(a)

(a) Universidade Federal de Santa Maria UFSM, School of Dentistry, Department of Restorative Dentistry, Santa Maria, RS, Brazil.

(b) Centro Universitário Franciscano, School of Dentistry, Santa Maria, RS, Brazil.
Declaration of Interests: The authors certify that they have no commercial or associative interest that represents a conflict of interest in connection with the manuscript.

Corresponding Author:

Tatiana Militz Perrone Pinto

E-mail: tatimilitz@hotmail.com

DOI: 10.1590/1807-3107BOR-2015.vol29.0053

Submitted: Aug 17, 2014

Accepted for publication: Jan 02, 2015

Last revision: Feb 19, 2015

\begin{abstract}
There are few instruments available in Brazil for obtaining data on dental erosion among adults. For this reason, the interview entitled "A Survey on Hong Kong People's Dietary Behavior in Relations to Acid Erosion", published in English, was considered for translation. The aim of this study was to perform a cross-cultural adaptation and content validation for the Brazilian population. After obtaining the author's permission, the interview underwent several stages: translation, back translation, review by a bilingual person and a committee of experts, administration of the English instrument and of the Portuguese version to a bilingual group, and pretesting in a convenience sample of 50 adults. The interview was translated and adapted to the Portuguese language and the Brazilian culture. The analysis of the data revealed that the interview was easy to apply, conduct and understand; therefore, it was considered viable and capable of being used in different studies.
\end{abstract}

Keywords: Validation Studies; Questionnaires; Translating; Tooth Erosion; Perception.

\section{Introduction}

A survey conducted by the University of Hong Kong with 520 participants, having a mean age of 37 years, was applied to investigate the degree of knowledge and self-perception of dental erosion and dietary habits. It was observed that approximately two-thirds of the participants $(64 \%)$ attended dental care sessions at least once a year. Acid fruits were among the most consumed foods (89\%), and after being informed about the signs and symptoms of dental erosion, $92 \%$ recognized that their teeth had undergone "changes", such as enamel wear, fractures at the extremities and dentin hypersensitivity. A high percentage of the respondents (71\%) never received any information about dental erosion, and 53\% believed that it was the same as caries. The results from this survey showed that a large portion of this population presented signs and symptoms associated with dental erosion and also lack of awareness on the subject. ${ }^{1}$

In Brazil, despite the scientific community's growing interest in researching this topic, there are few data relative to dental erosion in adults, and no questionnaire that investigates self-perception, risk 
factors and knowledge of dental erosion in adults. Therefore, the relevance of a cross-cultural adaptation of this kind of questionnaire and/or interview is unquestionably valid.

Cross-cultural adaptation involves different stages until the final instrument is obtained in the new language. This process becomes complex, since the culture of the countries involved, as well as the language, context and lifestyle of the respective populations, should be considered in a distinct manner.

The cross-cultural adaptation of instruments not only saves time and effort, but also promotes exchange and collaboration among members of the scientific community. ${ }^{2}$ Different studies tend to use questionnaires for data collection; these are mostly in a different language from that in which they were initially developed. However, it is important to seek equivalence between the original and the target instrument, so as to contemplate adaptations between different countries, cultures, and languages, as well as local and regional adjustments. ${ }^{3}$ Therefore, in order to adapt an instrument to another language, certain linguistic, semantic and technical aspects should be considered. ${ }^{4}$

Different guidelines and theoretical approaches to achieve content validation of instruments are discussed in the literature. The general recommendation is that there should be a translation of phrases and words associated with a committed search for significance and meaning in the cultural context and lifestyle of the target population. With today's increasing interchange of information, the trend is toward the standardization of international guidelines to ensure the quality of the adapted instruments. Generally, the different stages of cross-cultural adaptation comprise: initial translation, back-translation, committee review and validation of the psychometric properties of the instrument. ${ }^{1,2,3,4,5}$ Cross-cultural adaptation is recommended, when possible, rather than the development of a new instrument. The advantages of this approach are the preservation of the reliability and validity of the original instrument, the greater simplicity of the process, and the possibility of comparing the existing data with new data, on an international level. ${ }^{6,7,8}$

In a systematic review concerning the cross-cultural adaptation of quality of life indices related to oral health, 29 cross-cultural adaptations were analyzed. The results revealed that many studies do not follow certain pre-established standards, such as: number and characteristics of the translators, whether or not the work was submitted to a review committee, and selection of participants and preliminary application of the instrument to a small group. It was found that the number of translators ranged between 1 and 5 . It was further verified that the number of respondents in the pretest ranged between 13 and 19, and that none of the studies used bilingual groups, because of the difficulty in applying this stage. ${ }^{7}$

Evidence has shown that the universalist approach is the most appropriate for cross-cultural adaptation research, because it reflects the reality of the different cultures involved. ${ }^{8}$ With the intent of implementing a universalist approach, this study proposed the cross-cultural adaptation and content validation to the Portuguese language and Brazilian culture of the interview: "A survey on Hong Kong people's dietary behavior in relations to acid erosion", published in the English language. ${ }^{1}$

\section{Methodology}

The present study was approved by the Research Ethics Committee of the Universidade Federal de Santa Maria - UFSM, Brazil (CAAE: 00558312.2.0000.5346), and does not present any conflicts of interest. Initially, an authorization from the author of the "Survey on Hong Kong People's Dietary Behavior in Relations to Acid Erosion" was requested. This request was made by e-mail, and the cross-cultural adaptation process began after authorization was received.

\section{Original Questionnaire}

The original questionnaire was composed of four sections. The first section requested demographic information. The second evaluated dental visit behavior, caries experience, and dietary habits. The third section contained questions that investigated the respondents' knowledge and self-reported signs and symptoms that could be related to dental erosion. The final section addressed attitudes and actions toward dental erosion. 


\section{Cross-cultural adaptation}

The process of cross-cultural adaptation of the questionnaire was based on the "Guidelines for cross-cultural adaptation of self-reported measures", published in 2000 by Beaton et al., ${ }^{5}$ which involves a process consisting of at least 5 stages: I -Translation, II - Synthesis, III - Back-translation, IV - Expert committee review, and V - Pretesting.

\section{Translation and Back-translation}

Two translations (T1 and T2) of the original instrument into the target language were made by different translators. T1 and T2 were submitted to a back-translation (BT1 and BT2) by two other translators who had no knowledge of the purpose of the work. All of the translators involved in the process were independent, bilingual, had a university degree in English from UFSM, and had the same skills and characteristics.

\section{Synthesis}

BT1 and BT2 were compared to the original instrument by a researcher from the area of dentistry, who had resided for 4 years in a country where English is an official language. After revision, small differences, which could cause some difficulty in linguistic and/or semantic interpretation, were noticed; some adjustments were made to T1 and T2, which generated a synthetic version of the instrument in Portuguese.

\section{Expert Committee Review}

A committee of experts composed of three dentistry professors having a PhD degree, who understood both languages (English and Portuguese), evaluated the synthetic version. The committee had not accompanied the previous stages of the process. They compared the Portuguese version with the original instrument, considering mainly two aspects: clarity in the expression of ideas and questions, and content fidelity. Small alterations were made with the purpose of preserving the characteristics of the original instrument, adapting this instrument to the local culture and maintaining the clarity, after which a pretest version was generated.

\section{Pretest - Bilingual Group}

The pretest version and the original instrument were applied to a bilingual group composed of a convenience sample of 25 students attending the second year of the English course at the UFSM. They were over 18 years of age, agreed to participate and signed the informed consent form. The students were divided randomly into two groups; Group 1 received the original interview in English, and Group 2, the pretest version. After seven days, the interview was applied again to the two groups; however, Group 1 responded the version in Portuguese and Group 2, the version in English. A comparison of the answers of each respondent to both instruments (pretest and original) was made, and the Kappa intraobserver test was applied to verify the agreement and level of replicability between the original and the translated versions of the questionnaire. The Kappa test revealed substantial agreement; thus, the pretest version was considered acceptable, with an adequate level of replicability.

\section{Pretest - Patients}

To evaluate the feasibility of the conduction and understanding of the instrument, the final, translated and adapted version was applied to a sample of individuals. A convenience sample of 50 individuals was selected among the patients attending the adult dental clinic of the UFSM. The respondents were approached individually and invited to answer the questionnaire. Those who agreed and signed the Informed Consent Form were interviewed.

\section{Results}

The original instrument and an initial version of the interview were administered to a bilingual group of 25 individuals. The answers of both questionnaires were compared with the purpose of finding the equivalence between the English and Portuguese versions. Substantial agreement was found between the responses, with Kappa values ranging from 0.63 to 1.0 .

Afterwards, a convenience sample was selected among the patients attending the adult dental clinic of the UFSM, Brazil for pretesting. The ranged between 25 and 45 years, and $80 \%$ were female. All 
of the participants had completed basic education, $36 \%$ attended high school and $12 \%$ had a university degree. The respondents' income was not requested in the pretest stage, because modifications to the proposed income values had to be made to adjust this question to the Brazilian reality. Thus, income values may vary over the years, and this issue could cause discomfort to the respondents. After reviewing the income question, it was easy to add it to the final version, using the Brazilian minimum wage as a reference.

In the pretesting stage, the interview was applied in a direct manner. This allows the interviewer to provide additional information, when necessary. The question order was changed and the subtitles were removed, leaving information about demographic data, self-perception and knowledge of dental erosion in the first part. The second part involved questions concerning attitudes, treatment, diet, risk factors and signs and symptoms that can be related to dental erosion. The option "incomplete higher education" was added to question number 3 , an alternative not available in the original interview.

The committee of experts suggested modifications to the translation of the words "housewife" and "teenager". The first was replaced by the equivalent in Portuguese: dona-de-casa, and the latter, by the expression mais jovem (younger). The term "signs" was added to question number 11 of the first part of the interview and to questions number 1, 2, 3 and 4 of the second part of the interview.

The final version of the instrument, translated and adapted to the Brazilian culture, may be seen in Figure.

\section{Discussion}

Historically, the process of cross-cultural adaptation of instruments has undergone modifications. At first, only the translation and the comparison of the instruments were performed. Small alterations were proposed if needed. Afterwards, still from a fractional point of view, the main focus was on translation and back-translation, ignoring the cultural aspects between the populations involved, in a procedure denominated absolutist. ${ }^{3}$ Currently, the new models proposed by the literature ${ }^{2,3,4,5,6,7}$ have adopted a universalist approach. Thus, not only the translation and backtranslation stage, but also the cultural adaptation stage is now considered, and further complemented with an idiomatic and cultural equivalence. A committee of experts examines and revises the translated and adapted version, which is subsequently pretested on a bilingual group or a sample of 30-40 persons. $^{7}$

In this context, the present study followed the universal models, which consider not only the language but also the context involved. This is particularly important in human and biological sciences, in which subtle differences may lead to different interpretations. ${ }^{9}$ In the present study, the content validation and cross-cultural adaptation consist of translation, back-translation, review by a committee of experts, administration of the preliminary and original version to a group of bilingual individuals, and pretesting of the final version in a sample of 50 adult patients.

During the different stages of the methodology, the terms that were not adequate were gradually changed and adapted. It is essential to make adjustments between the denotative and connotative meanings that the different terms assume in the new cultural context. Literal correspondence does not always cause the same reaction or impact on the target population and may alter the psychometric properties of the instrument. Additionally, the impact made by the new version should be as close as possible to that of the original instrument. ${ }^{10}$

One of the changes proposed in the cross-cultural and content validation of the instrument was the exclusion of the secondary titles: "People's perception towards acidic erosion of teeth, People's attitude towards acidic erosion of teeth, Impacts of symptoms of acidic erosion of teeth on people's daily lives, How people deal with symptoms of acidic erosion of teeth, Relationship between people's eating habits and acidic erosion of teeth, and Respondent's demographic information". In the original instrument, these topics acted as support elements in the organization and interpretation of the data, and were not read during the interview. Thus, the translation of these titles was unnecessary, since they were not part of the questionnaire and did not provide specific information 
about the interviewed individual; as such, they were not considered in the statistical analysis.

Question number 1 asks whether the individual is in the age range of the target population. It was also removed, since a series of informal questions were asked before the interview began, in an informal manner, to determine whether the individual was in conformity with the inclusion/exclusion criteria. If not, he/she would not be included in the research, thus dispensing the need to include this question in the final version of the instrument. Question number 17, which deals with the individual's monthly income, was not included in the pretest, considering that the values proposed could vary over the years, and this issue could cause discomfort to the respondents. However, it was easy to insert it in the final version, using the Brazilian minimum wage as a reference, without requiring human resources specialized in translation.

The new version of the questionnaire was subdivided into two sections, the first with eleven (11) questions, and the second with 8 (eight) questions. The layout and question order were changed, leaving questions about the respondent's demographic data, self-perception and knowledge of dental erosion in the first part. In the second part, there is a small introduction that explains dental erosion and its signs and symptoms, followed by 8 questions that evaluate the respondent's dietary and oral hygiene habits. The second part also identifies how the individuals deal with fear, and how they seek treatment of the potentially erosive lesions. Thus, the complexity was gradually detailed, starting with general and demographic data (first part) and approaching more specific and behavioral aspects, in the second part.

The mode of administration of the questionnaire for data collection is one of the elements of operational equivalence. It should not be up to the interviewer to decide the way the questionnaire should be conducted or applied. This decision should depend on the circumstances in which the instrument is to be used. ${ }^{3}$ During administration of the questionnaire to the bilingual groups, some respondents asked for additional information. For this reason, it was decided that the questionnaire should be applied in a direct manner. Instead of respondents answering the questions silently and individually, the interviewer read the question and the items under it, and provided the necessary explanations, so that the answer would be as accurate as possible. Moreover, application in the form of an interview allows all the questions to be answered, increasing the response rate in comparison with self-administered questionnaires. Application by interview also gives individuals with different educational levels the opportunity to participate; however, the interviewer must be mindful not to persuade or influence the respondents in their answers. ${ }^{11}$

The purpose of the pretest is to detect possible discrepancies of language or contextual inconsistencies. In addition, this phase should evaluate the equivalence of each item or question relative to the instrument. ${ }^{4,5}$ This stage involved the application of the two questionnaires (original instrument and adapted version) to a bilingual group, followed by pretesting of the new version with a convenience sample of 50 adults that attended the University Clinic.

After the comparative evaluation of the responses of the bilingual groups, some modifications were required. In question number 3 , the respondents were asked about their educational background; the options available in the original instrument were: primary, secondary, higher education or above, and refusal to answer. The option "incomplete higher education" was added to this question, because in the course of adapting the instrument to the bilingual groups, it was noticed that many respondents felt uncomfortable marking the option "secondary", and some added "incomplete higher education" to their responses manually, because this alternative was not given.

After the instrument was evaluated by the committee of experts, the term "signs" had to be added to question number 11 of the first part of the interview, and to questions number 1, 2, 3 and 4 of the second part of the interview, because some of the characteristics described are signs and not symptoms, as appears in the original instrument. Apart from these alterations and additions, the committee suggested other adjustments: the term "housewife", initially translated as do lar, was replaced by dona-de-casa, which is the more common term in Brazilian culture. The term "teenager", which was 
translated as adolescente (adolescent), was replaced by mais jovem (younger), a term that, in this case, is more contextually related to time than to puberty.

The application of the interview to a convenience sample of patients tested the efficacy and operationality of the instrument, seeing that its adapted version underwent some variations in the mode of its application and the scenario of its administration. Thus, the practical results revealed that, overall, there was no difficulty in its conduction, and, as expected, dental erosion continues to be a subject that has not been popularly disseminated, and on which very little information is made available to the population. The face-to-face interview proved effective in delivering the questions consistently.

It must be borne in mind that the construction of knowledge must go through stages of growth and consolidation. This process requires time for the interaction between theory and experimentation. ${ }^{12}$ Therefore, since the instrument now validated and adapted to the Brazilian culture has only recently been developed, it is possible that it may still require a period of maturation, with the purpose

\section{References}

1. Chu $\mathrm{CH}$, Pang KKL, Lo ECM. Dietary behavior and knowledge of dental erosion among Chinese adults. BMC Oral Health. 2010 Jun;10:13. DOI: 10.1186/1472-6831-10-13.

2. Guillemin F, Bombardier C, Beaton D. Cross-cultural adaptation of health-related quality of life measures: literature review and proposed guidelines. J Clin Epidemiol. 1993 Dec;46(12):1417-32.

3. Reichenheim ME, Moraes CL. Operationalizing the crosscultural adaptation of epidemiological measurement instruments. Rev Saude Publica. 2007 Aug;41(4):665-73.

4. Patrick DL, Sittampalam Y, Somerville SM, Carter WB, Bergner M. A cross-cultural comparison of health status values. Am J Public Health. 1985 Dec;75(12):1402-7.

5. Beaton DE, Bombardier C, Guillemin F, Ferraz MB. Guidelines for the process of cross-cultural adaptation of self-report measures. Spine (Phila Pa 1976). 2000 Dec 15;25(24):3186-91.

6. Casas Anguita J, Repullo Labrador JR, Pereira Candel J. Measurements of quality of life related with health. Basic concepts and cultural adaptation. Med Clin (Barc). 2001 Jun 2;116(20):789-96. Spanish. of consolidating the results. It should be noted that content validity and cross-cultural adaptation does not address the construct validity; additional testing of the psychometric properties of the questionnaire is highly recommended. ${ }^{5}$

\section{Conclusions}

The present study is the first attempt to develop a cross-cultural adaptation for the Brazilian population. The results showed that its level of replicability was substantial. Moreover, practical application of the instrument revealed that it was easy to conduct and understand, and was considered feasible and capable of being used in different studies. The pretest was applied to a small convenience sample of patients attending a university dental clinic; therefore, the results should not be presumed to apply to the general population. The cross-cultural adaptation was conducted in the southern region of Brazil. The geographic and cultural differences should be carefully considered when conducting this instrument in more distant and culturally diverse regions of the same country.

7. Castro RAL, Portela MC, Leão AT. Cross-cultural adaptation of quality of life indices for oral health. Cad Saude Publica. 2007 Oct;23(10):2275-84. Portuguese.

8. Alexandre NM, Guirardello EB. Cultural adaptation of instruments utilized in occupational health. Rev Panam Salud Publica. 2002 Feb;11(2):109-11. Spanish.

9. Conti MA, Hearst N, Latorre MRDO. Translation and validation for Brazil of the body image scale for adolescents: Offer Self Image Questionnaire (OSIQ). Rev Bras Epidemiol. 2011 Sep;14(3):508-21. Portuguese.

10. Herdman M, Fox-Rushby J, Badia X. Equivalence and the translation and adaptation of health-related quality of life questionnaires. Qual Life Res. 1997 Apr;6(3):237-47.

11. Furtado GES, Sousa MLR, Martinez-Mier ELA, Silva DD, Deschamps N, Almeida MEL. Tradução e adaptação cultural para o Brasil de um instrumento para verificar percepção da estética dentária. Rev Bras Prom Saude. 2010 OctDec;23(4):316-24.

12. Reichenheim ME, Moraes CL. Alguns pilares para a apreciação da validade de estudos epidemiológicos. Rev Bras Epidemiol. 1998;1(2):131-48. 
Figure. Translated and adapted version of interview.

Questionário - Parte I

\section{Gênero}

$\square$ Masculino

Feminino

\section{Idade}

$\square 25$ a 30

$\square 31$ a 35

36 a 40

41 a 45

$\square$ Recusa-se a responder

\section{Nível de escolaridade}

Ensino Fundamental completo ou incompleto

Ensino Médio

Ensino Superior incompleto

$\square$ Ensino Superior ou nível acima

$\square$ Recusa-se a responder

\section{Ocupação}

Trabalho por tempo integral (dois turnos)

Trabalho por tempo parcial (um turno)

Desempregado

Estudante

Aposentado

Dona de casa

Outros:

$\square$ Recusa-se a responder

\section{Renda individual mensal}

Até 1 salário mínimo

1 a 3 salários mínimos

$\square 3$ a 5 salários mínimos

$\square 5$ a 7 salários mínimos

$\square 7$ a 9 salários mínimos

$\square 9$ a 11 salários mínimos

$\square$ Mais que 11 salários mínimos

$\square$ Recusa-se a responder

6. Com que frequência, em média, você vai ao dentista?

Menos de uma vez por ano

1 vez por ano

2 vezes por ano

3 vezes por ano

4 vezes por ano

5 vezes por ano

\section{Continue}




\section{Continuation}

Mais que 5 vezes por ano

Não consulta um dentista

Não sabe/Tem dificuldade em responder

Recusa-se a responder

\section{Comparado a quando você era mais jovem seus dentes agora:}

Tornaram-se mais amarelados?

$\begin{array}{ll}\square \text { Sim } & \square \text { Não } \\ \square \text { Sim } & \square \text { Não } \\ \square \text { Sim } & \square \text { Não } \\ \square \text { Sim } & \square \text { Não } \\ \square \text { Sim } & \square \text { Não }\end{array}$

Tornaram-se mais brilhantes e lisos?

Tem bordas mais finas?

Tem fraturas nas bordas (extremidades)?

Apresentam-se doloridos ou com dor ao beber líquido gelado/ quente ou ingerir alimentos ácidos e ou/doces?

Não

ก̃o

Não

Não

$\square$ Nenhuma situação descrita

$\square$ Recusa-se a responder

\section{*Observação:}

Se o participante responder sim a quaisquer alternativas acima a entrevista continua.

Se o participante responder: Nenhuma situação descrita a entrevista é finalizada.

Se o participante se recusar a responder a entrevista é finalizada.

8. Você já teve cárie dentária ou já foi submetido a restaurações nos dentes?

$\square \operatorname{Sim}$

$\square$ Não

Recusa-se a responder

9. Você já ouviu falar em "erosão ácida" dos dentes?

$\square \operatorname{Sim}$

$\square$ Não

Não sabe/Tem dificuldade em responder

Recusa-se a responder

10. Você acredita que a erosão dental ácida é a mesma coisa que cárie dentária?

Sim

$\square$ Não

$\square$ Não sabe/Tem dificuldade em responder

Recusa-se a responder

11. Você sabe quais são os sintomas da erosão dental ácida?

Não tem conhecimento

Dentes tornam-se amarelados

Dentes com superfície mais lisa e brilhante

Dentes com bordas mais fina

Dentes com fraturas nas bordas

Sensação de dor ou de sensibilidade ao beber líquidos quentes e gelados ou comer alimentos ácidos ou doces

Ter cárie dentária

Outros:

$\square$ Recusa-se a responder.

Continue 


\section{Questionário - Parte II}

Os sintomas da erosão dental ácida são: dentes tornando-se amarelados, dentes apresentando superfície mais lisa e brilhante, dentes apresentando borda (extremidade, ponta) mais fina, dentes com leves fraturas na sua borda, sensação de dor, de sensibilidade ou de desconforto ao beber líquidos quentes e gelados ou ao comer alimentos ácidos e doces.

1. Aproximadamente com qual idade você apresentou os primeiros sinais ou sintomas de erosão dental ácida?

\section{0 anos ou menos}

21 a 30 anos

31 a 40 anos

41 a 45 anos

46 a 55 anos

Não consegue lembrar/Não sabe/Tem dificuldade em responder (pular para a questão 3)

Recusa-se a responder (pular para a questão 3)

2. Em outras palavras, há quanto tempo você tem apresentado esses sinais ou sintomas?

1 ano ou menos

2 a 3 anos

4 a 5 anos

6 a 10 anos

11 a 20 anos

Mais que 20 anos

Não consegue lembrar/Não sabe/Tem dificuldade em responder

Recusa-se a responder

3. Você está preocupado que os seus dentes possam apresentar os seguintes sinais ou sintomas:

Dentes amarelados

Dentes com uma superfície mais lisa e brilhante

Dentes com uma extremidade (borda, ponta) mais fina

Dentes com fraturas nas extremidades (bordas, pontas)

Dentes diminuindo de tamanho por causa da erosão ácida

Sem preocupação alguma/Nenhum dos sintomas acima.

Não sabe/Tem dificuldade em responder

Recusa-se a responder

4. Quando ou caso os sinais ou sintomas da erosão ácida dos dentes aparecerem, o que você faria para enfrentá-los?

Não faria nada

Escovaria os dentes imediatamente após ingerir algo

Escovaria os dentes com maior frequência

Escovaria os dentes com mais força

Mascaria chicletes sem açúcar após ingerir algo

Mastigaria os alimentos de modo mais suave (gentil)

Trocaria de pasta dental 
Usaria fio dental, faria uma limpeza profissional (raspagem) ou clareamento

Diminuiria a ingestão de alimentos muito gelados ou quentes

Diminuiria a ingestão de alimentos doces

Diminuiria a ingestão de alimentos ácidos

Diminuiria a ingestão de bebidas ou alimentos que causam sensibilidade

Consultaria um dentista

Faria uma revisão dental regularmente

Outros:

Não sabe/Tem dificuldade em responder

Recusa-se a responder.

5. Você acredita que as opções a seguir são tratamentos corretos para a erosão ácida dos dentes? (múltiplas respostas são permitidas)

Escovar seus dentes imediatamente após ingerir de algo

Escovar seus dentes com maior frequência

Escovar seus dentes com mais força

Esfregar rodelas de limão contra os dentes para clarear os dentes que estão amarelados

Nenhuma das opções acima

Não sabe/Tem dificuldade em responder

Recusa-se a responder.

6. Você costuma fazer as seguintes refeições:

Café da manhã

Almoço

$\square$ Jantar

Nenhuma das respostas acima

$\square$ Não sabe/Tem dificuldade em responder

Recusa-se a responder

7. Com que frequência, em média, você toma bebidas diferentes de água pura ou chá puro, e come entre as refeições (incluindo refrigerante, café, lanches, frutas, sobremesas, etc.)? Por favor, inclua a frequência entre café da manhã e almoço, almoço e jantar e após o jantar até a hora de ir dormir. Conte como uma vez até mesmo se você tenha ingerido apenas um doce (bala, bombom).

$\square$ Nenhuma

1 a 2 vezes

3 a 4 vezes

5 a 6 vezes

7 a 8 vezes

9 a 10 vezes

Mais que 10 vezes

Não sabe/Tem dificuldade em responder

Recusa-se a responder

Continue 


\section{Continuation}

8. Por fim, você tem o hábito de consumir os seguintes líquidos ou alimentos? Se a resposta for positiva, informar a frequência.

\begin{tabular}{|c|c|c|c|c|c|c|c|}
\hline Bebidas & Frutas & Sucos & Refrigerantes & Chás & Água & $\begin{array}{l}\text { Vinho } \\
\text { tinto/ } \\
\text { branco }\end{array}$ & $\begin{array}{l}\text { Lanches ácidos } \\
\text { como balas azedas, } \\
\text { frutas secas, }\end{array}$ \\
\hline Várias vezes ao dia & & & & & & & \\
\hline Uma vez ao dia & & & & & & & \\
\hline Uma vez na semana & & & & & & & \\
\hline $\begin{array}{l}\text { Várias vezes } \\
\text { durante a semana }\end{array}$ & & & & & & & \\
\hline Esporadicamente & & & & & & & \\
\hline Nunca & & & & & & & \\
\hline
\end{tabular}

Outros:

Não sabe/Tem dificuldade em responder

$\square$ Recusa-se a responder 